\title{
Some of the Properties of Heat-Treated Sessile Oak (Quercus petraea)
}

\author{
Suleyman Korkut \\ Selman Karayilmazlar \\ Salim Hiziroglu \\ Tolunay Sanli
}

\begin{abstract}
The objective of this study was to investigate the effects of heat treatment on the physical and mechanical properties of sessile oak (Quercus petraea). Samples were exposed to three temperature levels of $120^{\circ} \mathrm{C}, 150^{\circ} \mathrm{C}$, and $180^{\circ} \mathrm{C}$ for time periods ranging from 2 to 10 hours. Modulus of elasticity, modulus of rupture, compression strength parallel-to-grain, hardness, impact bending, tension strength, swelling in three sections, and surface roughness of the samples were evaluated. Based on the findings in this study, the results showed a significant difference between properties of control samples and heat-treated samples $(P=0.05)$. Mechanical properties of the samples were adversely influenced as a result of heat treatment; however, surface quality and dimensional stability of the samples improved with heat treatment. Changes in properties of the samples were more pronounced as temperature and exposure times were increased.
\end{abstract}

$\mathrm{T}_{\mathrm{t}}$ he genus Quercus is native to the northern hemisphere, extending from temperate areas to tropical Asia and North America. Sessile oak (Quercus petraea) is also known as Durmast oak and is a native species in most European countries and Anatolia (Yaltirik and Efe 2000). It spreads over 6,068,920 ha, which is almost 29 percent of the total forest land of Turkey (Konukcu 1998, Anonymous 2001).

Sessile oak trees may be up to $30 \mathrm{~m}$ in height and have excellent mechanical properties. The species is important in the lumber industry in Turkey and is widely used for different applications including manufacturing of furniture, axles, handles, splitting wedges, novelty items, interior paneling, flooring, timber frame, veneer, wine barrels, fuel, and charcoal (Bozkurt and Erdin 1997, 1998). It is well known that solid wood has certain undesirable properties such as poor resistance against biological deterioration and dimensional instability due to its hygroscopic nature (Kocaefe et al. 2008b).

Based on past studies, heat treatment at relatively high temperatures, ranging from $150^{\circ} \mathrm{C}$ to $260^{\circ} \mathrm{C}$, was found to be an effective method to improve dimensional stability and durability of wood (Seborg et al. 1953; Kollmann and Schneider 1963; Stamm 1964; Kollmann and Fengel 1965; Noack 1969; Burmester 1973, 1975; Giebeler 1983; Hillis 1984; Bourgois and Guyonnet 1988; Sanli 2008). Thermally treated wood has been investigated since the middle of the last century, and thermal modification of wood has become a well-established procedure. There is a growing number of industrial treatment centers in various European countries.
Thermally treated products manufactured by thermowood (Stellac) in Finland, torrefaction (perdure) in France, and PLATO-wood in the Netherlands are some of the examples of this technology (Inoue et al. 1993, Boonstra et al. 1998, Militz 2002, Anonymous 2003, Kocaefe et al. 2008b). Temperatures over $150^{\circ} \mathrm{C}$ permanently alter the physical and chemical properties of wood. Having higher treatment temperature also enhances biological durability, but some undesirable effects such as reduction of strength and hardness of wood are inevitable (Sandermann and Augustin 1963, Rusche 1973, Kubojima et al. 2000). Thermally treated wood is more brittle, and bending and tension strength characteristics are decreased by 10 to 30 percent. Therefore, the use of heat-treated wood in load-bearing applications is not suggested (Anonymous 2003).

The change in properties of wood is mainly caused by thermic degrading of hemicelluloses. Theoretically, the available hydroxyl groups in hemicellulose have the most significant effect on the physical properties of wood. The

The authors are, respectively, Assistant Professor, Duzce Univ., Duzce, Turkey (suleymankorkut@duzce.edu.tr); Professor, Bartin Univ., Bartin, Turkey (selmankzku@yahoo.com); Professor, Oklahoma State Univ., Stillwater (salim.hiziroglu@okstate.edu); and PhD Student, Fagus Forest Products Inc., Antalya, Turkey (tolunay-sanli@hotmail.com). This paper was received for publication in May 2010. Article no. 10-00002.

(c)Forest Products Society 2010.

Forest Prod. J. 60(5):473-480. 
Table 1.-Results of physical properties of the samples. ${ }^{a}$

\begin{tabular}{|c|c|c|c|c|c|c|c|c|c|c|}
\hline \multirow{2}{*}{$\begin{array}{c}\text { Heat } \\
\text { treatment } \\
\text { and time }\end{array}$} & \multirow[b]{2}{*}{ Unit } & \multirow{2}{*}{$\begin{array}{c}\text { Ovendry } \\
\text { density, } \\
D_{0}\left(\mathrm{~g} / \mathrm{cm}^{3}\right) \\
\end{array}$} & \multirow{2}{*}{$\begin{array}{c}\text { Air-dry } \\
\text { density, } \\
D_{12}\left(\mathrm{~g} / \mathrm{cm}^{3}\right) \\
\end{array}$} & \multicolumn{4}{|c|}{ Surface roughness $(\mu \mathrm{m})$} & \multicolumn{3}{|c|}{ Swelling (\%) } \\
\hline & & & & $R_{a}$ & $R_{y}$ & $R_{z}$ & $R_{q}$ & Radial & Tangential & Longitudinal \\
\hline \multirow[t]{3}{*}{ Control } & Avg & $0.71 \mathrm{~A}$ & $0.72 \mathrm{~A}$ & $10.32 \mathrm{~A}$ & $115.06 \mathrm{~A}$ & $78.33 \mathrm{~A}$ & $14.90 \mathrm{~A}$ & $5.76 \mathrm{~A}$ & $9.57 \mathrm{~A}$ & $1.07 \mathrm{~A}$ \\
\hline & $\mathrm{SD}$ & 0.08 & 0.08 & 3.11 & 37.7 & 18.31 & 4.92 & 0.97 & 2.59 & 0.31 \\
\hline & $\mathrm{CV}$ & 12.38 & 12.07 & 30.13 & 32.77 & 23.38 & 33.05 & 16.93 & 27.11 & 28.99 \\
\hline \multicolumn{11}{|l|}{$120^{\circ} \mathrm{C}$} \\
\hline \multirow[t]{3}{*}{$2 \mathrm{~h}$} & Avg & $0.71 \mathrm{ABCDE}$ & $0.71 \mathrm{ABC}$ & $9.66 \mathrm{AC}$ & $113.5 \mathrm{AB}$ & $75.77 \mathrm{AC}$ & $14.79 \mathrm{AB}$ & 5.55 ADEFGH & $9.04 \mathrm{AEFGH}$ & 0.97 ACDEFGH \\
\hline & SD & 0.09 & 0.078 & 1.72 & 29.72 & 24.63 & 4.22 & 17.99 & 1.36 & 0.32 \\
\hline & $\mathrm{CV}$ & 12.76 & 10.999 & 17.86 & 26.18 & 32.5 & 28.57 & 17.93 & 15.09 & 33.35 \\
\hline \multirow[t]{3}{*}{$6 \mathrm{~h}$} & Avg & $0.7 \mathrm{ABCDE}$ & $0.7 \mathrm{AC}$ & $9.59 \mathrm{AC}$ & $108.53 \mathrm{AB}$ & $75 \mathrm{AC}$ & $14.04 \mathrm{AB}$ & 5.49 ADEFGH & 9.04 AEFGH & 0.96 ADEFGH \\
\hline & SD & 0.004 & 0.074 & 2.68 & 38.92 & 23.14 & 2.937 & 1.032 & 2.09 & 0.27 \\
\hline & $\mathrm{CV}$ & 9.116 & 10.561 & 27.92 & 35.86 & 30.85 & 20.91 & 18.78 & 23.21 & 28.68 \\
\hline \multirow[t]{3}{*}{$10 \mathrm{~h}$} & Avg & $0.7 \mathrm{ABCDE}$ & $0.7 \mathrm{AC}$ & $9.57 \mathrm{AC}$ & $107.4 \mathrm{AB}$ & $73.81 \mathrm{AC}$ & $13.93 \mathrm{AB}$ & $5.15 \mathrm{BGH}$ & 8.42 BEFGH & $0.86 \mathrm{~B}$ \\
\hline & $\mathrm{SD}$ & 0.072 & 0.065 & 2.123 & 25.41 & 22.29 & 3.219 & 0.807 & 2.12 & 0.13 \\
\hline & $\mathrm{CV}$ & 10.29 & 9.297 & 22.16 & 23.65 & 30.2 & 23.1 & 15.67 & 25.21 & 15.29 \\
\hline \multicolumn{11}{|l|}{$150^{\circ} \mathrm{C}$} \\
\hline \multirow[t]{3}{*}{$2 \mathrm{~h}$} & Avg & $0.69 \mathrm{AE}$ & $0.7 \mathrm{AC}$ & $9.32 \mathrm{AC}$ & $107.15 \mathrm{AB}$ & $73.56 \mathrm{AC}$ & $13.77 \mathrm{AB}$ & $5.131 \mathrm{CGH}$ & $8.15 \mathrm{CFGH}$ & $0.84 \mathrm{C}$ \\
\hline & SD & 0.05 & 0.154 & 1.459 & 38.36 & 12 & 4.308 & 0.944 & 1.052 & 0.193 \\
\hline & $\mathrm{CV}$ & 8.1 & 22 & 15.65 & 35.8 & 16.31 & 31.28 & 18.39 & 12.91 & 22.97 \\
\hline \multirow[t]{3}{*}{$6 \mathrm{~h}$} & Avg & $0.69 \mathrm{AE}$ & $0.69 \mathrm{AC}$ & $9.1 \mathrm{AC}$ & $104.41 \mathrm{AB}$ & $71.42 \mathrm{AC}$ & $13.66 \mathrm{AB}$ & 4.875 DGH & $8.08 \mathrm{DFGH}$ & $0.81 \mathrm{D}$ \\
\hline & SD & 0.078 & 0.079 & 3.06 & 27.01 & 18.17 & 2.917 & 0.858 & 1.866 & 0.172 \\
\hline & $\mathrm{CV}$ & 11.37 & 11.42 & 33.71 & 25.87 & 25.44 & 21.35 & 17.6 & 23.07 & 0.029 \\
\hline \multirow[t]{3}{*}{$10 \mathrm{~h}$} & Avg & $0.66 \mathrm{BE}$ & $0.69 \mathrm{AC}$ & $9 \mathrm{AC}$ & $103.782 \mathrm{AB}$ & $70.15 \mathrm{AC}$ & $13.56 \mathrm{AB}$ & $4.788 \mathrm{EH}$ & $7.4 \mathrm{EH}$ & $0.8 \mathrm{E}$ \\
\hline & $\mathrm{SD}$ & 0.06 & 0.07 & 2.11 & 24.16 & 14.5 & 3.57 & 0.846 & 2.06 & 0.152 \\
\hline & $\mathrm{CV}$ & 9.43 & 10.65 & 23.46 & 23.28 & 20.68 & 26.33 & 17.676 & 27.822 & 18.89 \\
\hline \multicolumn{11}{|l|}{$180^{\circ} \mathrm{C}$} \\
\hline \multirow[t]{3}{*}{$2 \mathrm{~h}$} & Avg & $0.66 \mathrm{C}$ & $0.69 \mathrm{AC}$ & $8.98 \mathrm{AC}$ & $100.81 \mathrm{AB}$ & $68.96 \mathrm{AC}$ & $12.89 \mathrm{~A}$ & $4.69 \mathrm{FH}$ & $7.06 \mathrm{~F}$ & $0.73 \mathrm{~F}$ \\
\hline & SD & 0.06 & 0.067 & 1.954 & 34.48 & 15.575 & 3.243 & 0.76 & 1.67 & 0.21 \\
\hline & $\mathrm{CV}$ & 9.1 & 9.804 & 21.752 & 34.205 & 22.583 & 25.15 & 16.23 & 23.65 & 27.22 \\
\hline \multirow[t]{3}{*}{$6 \mathrm{~h}$} & Avg & $0.65 \mathrm{D}$ & $0.66 \mathrm{~B}$ & $8.89 \mathrm{BC}$ & $99.43 \mathrm{AB}$ & $64.65 \mathrm{BC}$ & $12.78 \mathrm{~A}$ & $4.31 \mathrm{G}$ & $6.87 \mathrm{G}$ & $0.76 \mathrm{G}$ \\
\hline & SD & 0.07 & 0.03 & 1.863 & 27.44 & 16.39 & 3.222 & 0.786 & 1.417 & 0.23 \\
\hline & $\mathrm{CV}$ & 10.89 & 5.32 & 20.94 & 753.2 & 25.35 & 25.21 & 18.08 & 20.61 & 30.17 \\
\hline \multirow[t]{3}{*}{$10 \mathrm{~h}$} & Avg & $0.63 \mathrm{E}$ & $0.64 \mathrm{C}$ & $7.67 \mathrm{C}$ & $78.86 \mathrm{~B}$ & $48.37 \mathrm{C}$ & $11.311 \mathrm{~B}$ & $3.94 \mathrm{H}$ & $6.15 \mathrm{H}$ & $0.73 \mathrm{H}$ \\
\hline & $\mathrm{SD}$ & 0.035 & 0.052 & 1.98 & 29.61 & 15.38 & 3.69 & 0.61 & 1.253 & 0.225 \\
\hline & $\mathrm{CV}$ & 5.58 & 8.128 & 25.85 & 37.54 & 31.85 & 32.62 & 15.56 & 20.38 & 30.94 \\
\hline
\end{tabular}

a Number of samples in each test was 30 . Avg = average; $\mathrm{CV}=$ coefficient of variation. Within each column, values with the same letters are not significantly different between samples according to Duncan's multiple range test at $P<0.05$.

process of heat treatment is generally accompanied by breakage of the lignin-polysaccharide complex by organic acids released from hemicelluloses (Kocaefe et al. 2008a). The treatment reduces water intake and the wood cell wall absorbs less water because of the decrease of the amount of hydroxyl groups in the cell wall. As a result of the reduced number of hydroxyl groups, swelling and shrinking of wood are reduced. Additionally heat treatment results in varying amounts of weight loss, depending on the treatment temperature and exposure time. In a previous study, spruce (Picea abies) wood heat treated for 24 hours showed a weight loss of 0.8 and 15.5 percent at $120^{\circ} \mathrm{C}$ and $200^{\circ} \mathrm{C}$, respectively (Fengel 1966). Weight loss in beech (Fagus sylvatica) wood, treated at increased temperatures was found in another study as 8.1 and 9.8 percent at $150^{\circ} \mathrm{C}$ and $200^{\circ} \mathrm{C}$, respectively (Fengel and Wegener 1989). Red-brown discoloration of wood is also an important characteristic of heat-treated material (Bekhta and Niemz 2003). Such wood is suggested as an alternative material to dark-colored wood products from tropical species (Bourgois et al. 1991, Syrjänen et al. 2000, Bekhta and Niemz 2003). In general the change in timber properties during heat treatment depends mainly on temperature, temperature gradient, amount of water vapor, and heating time (Zaman et al. 2000).

The improved characteristics of heat-treated sessile oak wood could offer various potential opportunities to the timber product industry. Heat-treated wood is also an ecofriendly alternative to chemically treated wood, having uses for kitchen and sauna furniture, bathroom cabinets, and flooring material (Syrjanen and Oy 2001). To our knowledge, there is no information about the influence of heat treatment on the mechanical and physical properties of sessile oak grown in Turkey. Therefore, the main objective of this study was to evaluate the effect of heat treatment on the properties of sessile oak and to provide preliminary data so that treated wood can be used more widely and effectively by the wood product industry.

\section{Materials and Methods}

Five trees with an average age of 95 years and an average diameter at breast height of $38 \mathrm{~cm}$ were harvested at a site with an altitude of $850 \mathrm{~m}$ and a slope of 60 percent in northeastern Turkey (Turkish Standard [TS] 1984). Lumbers from the logs were sawn and planned (TS 1976a, TS 1981). Following air drying of the material, small and clear 
Table 2.-Reduction in physical properties of the samples as function of heat treatment.

\begin{tabular}{|c|c|c|c|c|c|c|c|c|c|}
\hline \multirow{2}{*}{$\begin{array}{l}\text { Heat treatment } \\
\text { and time }\end{array}$} & \multirow{2}{*}{$\begin{array}{c}\text { Ovendry } \\
\text { density (\%) }\end{array}$} & \multirow{2}{*}{$\begin{array}{c}\text { Air-dry } \\
\text { density (\%) }\end{array}$} & \multicolumn{3}{|c|}{ Swelling (\%) } & \multicolumn{4}{|c|}{ Surface roughness (\%) } \\
\hline & & & Radial & Tangential & Longitudinal & $R_{a}$ & $R_{y}$ & $R_{z}$ & $R_{q}$ \\
\hline \multicolumn{10}{|l|}{$120^{\circ} \mathrm{C}$} \\
\hline $2 \mathrm{~h}$ & 0.918 & 1.272 & 3.64 & 5.527 & 9.062 & 6.42 & 1.36 & 3.268 & 0.73 \\
\hline $6 \mathrm{~h}$ & 1.085 & 2.707 & 4.677 & 5.559 & 10.17 & 7.05 & 5.67 & 4.257 & 5.77 \\
\hline $10 \mathrm{~h}$ & 1.376 & 3.193 & 10.61 & 12.08 & 19.4 & 7.26 & 6.62 & 5.77 & 6.53 \\
\hline \multicolumn{10}{|l|}{$150^{\circ} \mathrm{C}$} \\
\hline $2 \mathrm{~h}$ & 2.844 & 3.215 & 11.02 & 14.89 & 21.31 & 9.73 & 6.88 & 6.09 & 7.64 \\
\hline $6 \mathrm{~h}$ & 3.715 & 3.908 & 15.47 & 15.57 & 23.83 & 11.85 & 9.25 & 8.824 & 8.35 \\
\hline $10 \mathrm{~h}$ & 7.788 & 4.231 & 16.97 & 22.67 & 24.62 & 12.81 & 9.81 & 10.44 & 8.98 \\
\hline \multicolumn{10}{|l|}{$180^{\circ} \mathrm{C}$} \\
\hline $2 \mathrm{~h}$ & 7.87 & 4.416 & 18.65 & 26.22 & 27.95 & 13 & 12.4 & 11.96 & 13.5 \\
\hline $6 \mathrm{~h}$ & 8.178 & 8.481 & 24.56 & 28.23 & 28.83 & 13.82 & 13.6 & 17.45 & 14.3 \\
\hline $10 \mathrm{~h}$ & 11.2 & 11.11 & 31.59 & 35.73 & 31.93 & 25.67 & 31.5 & 38.33 & 24.1 \\
\hline
\end{tabular}

specimens were cut from the boards according to TS 2472 , which is similar to ISO 3131 Standard to determine air-dry and ovendry densities $\left(D_{\mathrm{m} 12}, D_{\mathrm{m} 0}\right.$; TS 1976b, International Organization for Standardization [ISO] 1975), swelling (tangential, radial, longitudinal $[\alpha(\mathrm{t}, \mathrm{r}, 1)]$; TS 1983), compression strength parallel to grain $\left(\sigma_{\mathrm{c} / /} ;\right.$ TS 1976c), modulus of rupture (MOR; TS 1976d), modulus of elasticity in bending (MOE; TS 1976e), Janka hardness (crosssection, radial and tangential grain orientation [Hj]; TS 1982), impact bending strength ( $\sigma_{i} ;$ TS 1976f), and tension strength perpendicular to grain ( $\sigma_{\mathrm{z} \perp}$; TS $\left.1976 \mathrm{~g}\right)$. Specimens were divided into nine treatment groups, and a total of 30 test and 30 control samples were used from each group. The samples were subjected to heat treatment at $120^{\circ} \mathrm{C}, 150^{\circ} \mathrm{C}$, and $180^{\circ} \mathrm{C}$ for 2,6 , and 10 hours in a laboratory-type heating unit controlled to an accuracy of $\pm 1^{\circ} \mathrm{C}$ of temperature under the atmospheric pressure. Then the specimens were conditioned at a temperature of $20 \pm 2^{\circ} \mathrm{C}$ with 65 percent relative humidity according to TS 642 (TS 1997). The moisture content of the samples was 0 percent after heat treatment. Following heat treatment, samples reached to equilibrium moisture content ranging from 9 to 11 percent in a conditioning room. The air-dry density of the samples was also determined. Oven-dried specimens were measured and weighted at an accuracy of $0.01 \mathrm{~mm}$ and $0.001 \mathrm{~g}$ to determine their density. In the following step the samples were soaked in water at a temperature of $20 \pm 2{ }^{\circ} \mathrm{C}$ for 1 week to determine their swelling. Moisture content (M) of each specimen was also measured according to TS 2471 (TS 1976h), and strength values were corrected based on 12 percent moisture content by using the following strength conversion equation:

$$
\delta_{12}=\delta_{\mathrm{m}}\left[1+\alpha\left(M_{2}-12\right)\right]
$$

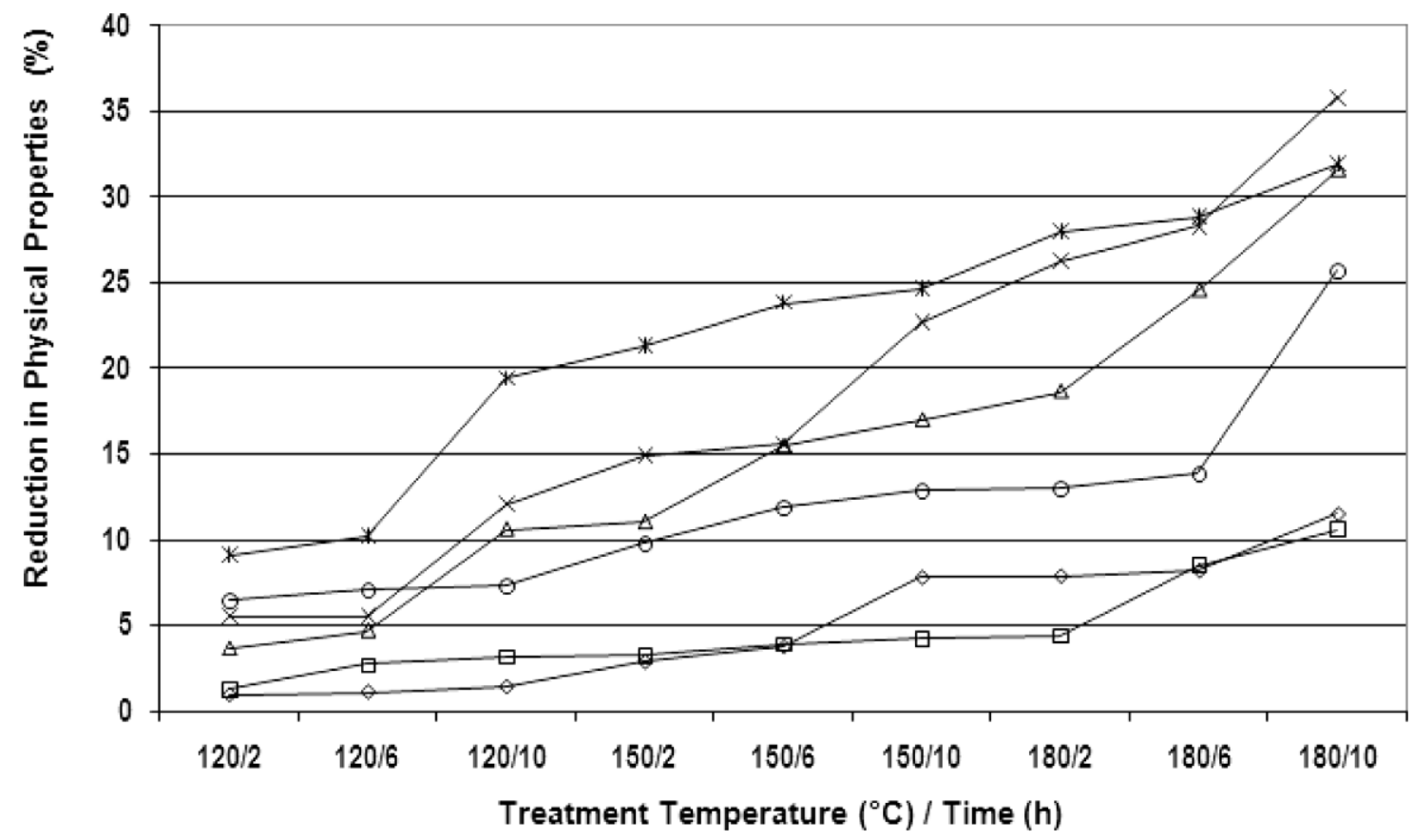

Figure 1.-Reduction in physical properties of the samples as function of heat treatment. $(\diamond)$ Ovendry density; ( $\square)$ air-dry density; $(\triangle)$ radial swelling; $(\times)$ tangential swelling; $(*)$ longitudinal swelling; $(O)$ surface roughness $\left(R_{a}\right)$. 
Table 3.-Results of mechanical properties of the samples as function of heat treatment. ${ }^{\text {a }}$

\begin{tabular}{|c|c|c|c|c|c|c|c|c|c|}
\hline \multirow{2}{*}{$\begin{array}{c}\text { Heat } \\
\text { treatment } \\
\text { and time }\end{array}$} & \multirow[b]{2}{*}{ Unit } & \multirow{2}{*}{$\begin{array}{l}\text { Comp. strength } \\
\left(\mathrm{N} / \mathrm{mm}^{2}\right)\end{array}$} & \multirow{2}{*}{$\begin{array}{c}\mathrm{MOR} \\
\left(\mathrm{N} / \mathrm{mm}^{2}\right)\end{array}$} & \multirow{2}{*}{$\begin{array}{c}\mathrm{MOE} \\
\left(\mathrm{N} / \mathrm{mm}^{2}\right)\end{array}$} & \multicolumn{3}{|c|}{ Janka hardness $\left(\mathrm{N} / \mathrm{mm}^{2}\right)$} & \multirow{2}{*}{$\begin{array}{c}\text { Impact } \\
\text { bending } \\
\left(\mathrm{J} / \mathrm{cm}^{2}\right)\end{array}$} & \multirow{2}{*}{$\begin{array}{l}\text { Tension strength } \\
\text { perpendicular } \\
\text { to grain }\left(\mathrm{N} / \mathrm{mm}^{2}\right)\end{array}$} \\
\hline & & & & & Cross section & Radial & Tangential & & \\
\hline \multirow[t]{3}{*}{ Control } & Avg & $64.08 \mathrm{~A}$ & $132.22 \mathrm{~A}$ & $13,882.4 \mathrm{~A}$ & $70.07 \mathrm{~A}$ & $34.47 \mathrm{~A}$ & $37.47 \mathrm{~A}$ & $8.16 \mathrm{~A}$ & $5.79 \mathrm{~A}$ \\
\hline & SD & 12.23 & 33.061 & $1,254.9$ & 8.203 & 4.36 & 4.5 & 2.102 & 1.34 \\
\hline & $\mathrm{CV}$ & 19.08 & 25 & 30.39 & 11.705 & 12.65 & 12.02 & 25.756 & 23.15 \\
\hline \multicolumn{10}{|l|}{$120^{\circ} \mathrm{C}$} \\
\hline \multirow[t]{3}{*}{$2 \mathrm{~h}$} & Avg & $63.14 \mathrm{AD}$ & 125.4 ABCDE & 11,679 ABCDEFGH & $67.36 \mathrm{ADE}$ & $33.926 \mathrm{ADEF}$ & 36.58 ADEFGH & 7.14 BHIK & 5.58 $\mathrm{ACDE}$ \\
\hline & SD & 12.74 & 27.3 & $1,476.63$ & 8.964 & 4.78 & 6.68 & 2.21 & 1.16 \\
\hline & $\mathrm{CV}$ & 20.18 & 21.77 & 18.26 & 13.307 & 14.1 & 18.26 & 30.94 & 20.78 \\
\hline \multirow[t]{3}{*}{$6 \mathrm{~h}$} & Avg & $61.28 \mathrm{AD}$ & $122.63 \mathrm{ACDE}$ & 11,163.6 ABCDEFG & $66.92 \mathrm{ADE}$ & $33.653 \mathrm{ADEF}$ & $34.84 \mathrm{AGH}$ & $6.642 \mathrm{CIK}$ & 5.4 $\mathrm{ACDE}$ \\
\hline & SD & 8.37 & 32.68 & $1,481.2$ & 8.042 & 5.118 & 6.08 & 1.614 & 1.218 \\
\hline & $\mathrm{CV}$ & 70.17 & 3.21 & 219,414 & 64.67 & 15.2 & 17.45 & 24.312 & 22.523 \\
\hline \multirow[t]{3}{*}{$10 \mathrm{~h}$} & Avg & $61.22 \mathrm{AD}$ & 120.52 ADE & 11,129 ABCDEFG & $66.78 \mathrm{ADE}$ & $32.736 \mathrm{AEF}$ & $33.68 \mathrm{BH}$ & $6.632 \mathrm{DIK}$ & 5.34 ACDE \\
\hline & $\mathrm{SD}$ & 9.543 & 29.46 & $3,306.64$ & 6.78 & 4.89 & 5.75 & 2.17 & 1.39 \\
\hline & $\mathrm{CV}$ & 15.58 & 24.44 & 29.7 & 10.16 & 14.94 & 17.09 & 32.72 & 26.12 \\
\hline \multicolumn{10}{|l|}{$150^{\circ} \mathrm{C}$} \\
\hline \multirow[t]{3}{*}{$2 \mathrm{~h}$} & Avg & $60.42 \mathrm{AD}$ & $115.1 \mathrm{AE}$ & $8,842 \mathrm{BFG}$ & $66.34 \mathrm{ADE}$ & $32.06 \mathrm{AF}$ & $33.626 \mathrm{CH}$ & $6.41 \mathrm{EIK}$ & $5.31 \mathrm{ACDE}$ \\
\hline & SD & 9.212 & 37.259 & 1,287 & 13.77 & 4.124 & 4.75 & 2.036 & 1.078 \\
\hline & $\mathrm{CV}$ & 15.245 & 32.369 & 14.563 & 20.759 & 12.865 & 14.127 & 31.765 & 20.285 \\
\hline \multirow[t]{3}{*}{$6 \mathrm{~h}$} & Avg & $59.86 \mathrm{AD}$ & $114.87 \mathrm{AE}$ & $8,713 \mathrm{CFG}$ & $65.53 \mathrm{ADE}$ & $31.313 \mathrm{BF}$ & $33.09 \mathrm{D}$ & 6.223 FIK & $5.28 \mathrm{ACDE}$ \\
\hline & SD & 11.011 & 37.528 & $1,726.87$ & 9.551 & 4.733 & 5.446 & 1.477 & 1.208 \\
\hline & $\mathrm{CV}$ & 18.393 & 32.668 & 19.81 & 14.576 & 15.11 & 16.45 & 23.74 & 22.85 \\
\hline \multirow[t]{3}{*}{$10 \mathrm{~h}$} & Avg & $59.41 \mathrm{AD}$ & 106.4 BE & $8,661 \mathrm{DFG}$ & $64.85 \mathrm{BE}$ & $31.233 \mathrm{CF}$ & $33.02 \mathrm{E}$ & 6.101 GIK & $4.98 \mathrm{BCDE}$ \\
\hline & $\mathrm{SD}$ & 9.833 & 27.066 & $1,986.37$ & 7.879 & 3.971 & 5.918 & 1.676 & 1.256 \\
\hline & $\mathrm{CV}$ & 16.55 & 25.438 & 22.93 & 12.149 & 12.716 & 17.923 & 27.476 & 25.22 \\
\hline \multicolumn{10}{|l|}{$180^{\circ} \mathrm{C}$} \\
\hline \multirow[t]{3}{*}{$2 \mathrm{~h}$} & Avg & $56.64 \mathrm{BD}$ & 105.16 CE & $8362 \mathrm{EG}$ & $62.9 \mathrm{CE}$ & $30.73 \mathrm{D}$ & $32.23 \mathrm{~F}$ & 5.819 HK 1.74 & $3.755 \mathrm{CE}$ \\
\hline & SD & 16.8 & 33.1 & $2,065.36$ & 5.522 & 6.03 & 4.677 & 29.96 & 0.81 \\
\hline & $\mathrm{CV}$ & 29.66 & 31.48 & 24.696 & 8.778 & 19.65 & 14.511 & 30 & 21.57 \\
\hline \multirow[t]{3}{*}{$6 \mathrm{~h}$} & Avg & $56.56 \mathrm{CD}$ & $101.44 \mathrm{D}$ & 7,994 FG & $60.73 \mathrm{D}$ & $29.73 \mathrm{E}$ & $31.19 \mathrm{G}$ & $4.95 \mathrm{I}$ & $3.46 \mathrm{D}$ \\
\hline & SD & 12.53 & 27.091 & 2,301 & 6.95 & 4.42 & 4.78 & 1.58 & 0.768 \\
\hline & $\mathrm{CV}$ & 22.16 & 26.7 & 28.79 & 11.45 & 14.88 & 15.33 & 31.96 & 22.19 \\
\hline \multirow[t]{3}{*}{$10 \mathrm{~h}$} & Avg & $50.42 \mathrm{D}$ & $85.52 \mathrm{E}$ & $7,553 \mathrm{G}$ & $57.87 \mathrm{E}$ & $28.38 \mathrm{~F}$ & $30.35 \mathrm{H}$ & $4.428 \mathrm{~K}$ & $3.138 \mathrm{E}$ \\
\hline & SD & 7.757 & 26.43 & $1,532.24$ & 6.258 & 4.749 & 5.052 & 1.52 & 0.723 \\
\hline & $\mathrm{CV}$ & 15.38 & 30.9 & 20.28 & 10.81 & 16.73 & 16.64 & 34.34 & 23.06 \\
\hline
\end{tabular}

a The number of samples in each test was 30. Avg = average; CV = coefficient of variation. Within each column, values with the same letters are not statistically different between samples according to the Duncan's multiple range test at $P<0.05$. Comparisons were between each control and its test.

where

$\delta_{12}=$ strength at 12 percent moisture content $\left(\mathrm{N} / \mathrm{mm}^{2}\right)$,

$\delta_{\mathrm{m}}=$ strength at moisture content deviated from 12 percent $\left(\mathrm{N} / \mathrm{mm}^{2}\right)$,

$\alpha=$ constant value showing relationship between strength and moisture content $(\alpha=0.05,0.04$, $0.02,0.025,0.015$, and 0.025 for $\sigma_{\mathrm{c} / /}, \mathrm{MOR}, \mathrm{MOE}$, $\sigma_{\mathrm{i}}, \sigma_{\mathrm{z} \perp}$, and $\mathrm{Hj}$, respectively), and

$M_{2}=$ moisture content during test (\%).

Surface roughness of the samples was measured by using a stylus-type profilometer (Mitutoyo Surftest SJ-301). The tracing speed, stylus tip diameter, and tip angle were 10 $\mathrm{mm} / \mathrm{min}, 4 \mu \mathrm{m}$, and $90^{\circ}$, respectively. Roughness measurements were taken randomly from the surface of the samples perpendicular to the grain orientation. Three roughness parameters, mean arithmetic deviation of profile $\left(R_{a}\right)$, mean peak-to-valley height $\left(R_{z}\right)$, maximum roughness $\left(R_{y}\right)$, and root mean square $\left(R_{q}\right)$, which were commonly used in previous studies, were used to evaluate surface characteristics of the samples (Stombo 1963). $R_{a}$ is the average distance from the profile to the mean line over the length of assessment. $R_{z}$ can be calculated from the peak-to-valley values of five equal lengths within the profile, while maximum roughness $\left(R_{y}\right)$ is the distance between peak and valley points of the profile that can be used as an indicator of the maximum defect height within the assessed profile (Hiziroglu 1996). Detailed specifications of these parameters are described in past studies (Mummery 1993, Hiziroglu 1996, ISO 1997). Roughness values were measured with a sensitivity of $0.5 \mu \mathrm{m}$. The tracing length (Lt) was $15 \mathrm{~mm}$ and the cut-off length was $\lambda=2.5 \mathrm{~mm}$. The measuring force of the stylus on the surfaces was $4 \mathrm{mN}(0.4$ g), which did not put any significant damage on the surface. For all parameters, multiple comparisons were first subjected to an analysis of variance (ANOVA) and significant differences between average values of control and treated samples were determined using Duncan's multiple range test at $P$ value of 0.05 (Kalipsiz 1994).

\section{Results and Discussion}

Table 1 displays densities, swelling ratios, and surface roughness parameters of the samples exposed to different treatments. In general ovendry and air-dry density values of the samples decreased insignificantly with increasing 


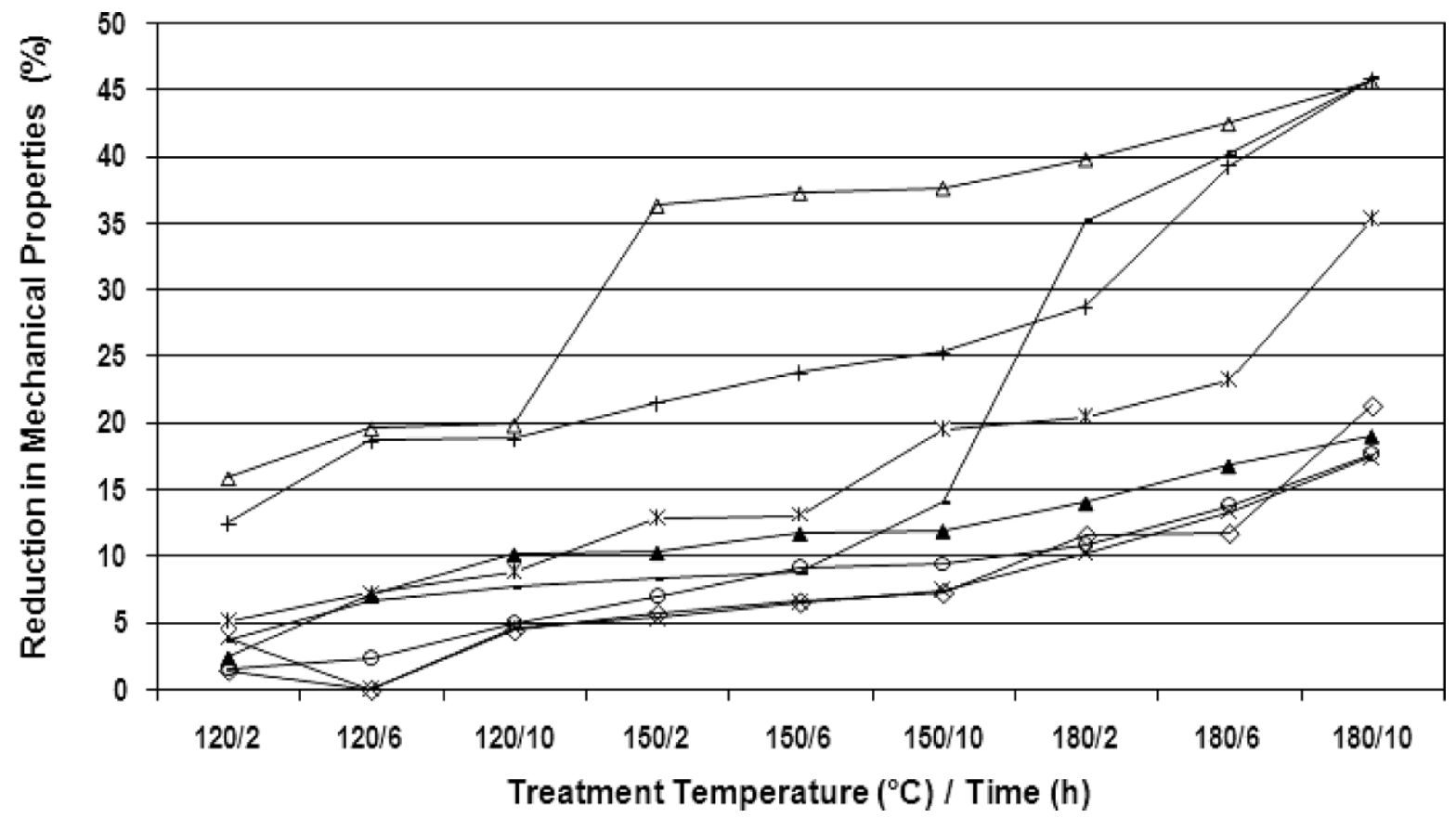

Figure 2.-Reduction in mechanical properties of the samples as function of heat treatment. ( $\diamond)$ Compression strength; $(*)$ modulus of rupture; $(\triangle)$ modulus of elasticity; $(\times)$ Janka hardness cross section; $(\bigcirc)$ Janka hardness radial; $(\boldsymbol{\Delta})$ Janka hardness tangential; (+) impact bending strength; (-) tension strength perpendicular to grain.

temperature and treatment periods. Samples exposed to a temperature of $180^{\circ} \mathrm{C}$ for 10 hours resulted in the lowest airdry and ovendry density values as compared with those treated under other conditions. Reduction in densities, and radial, tangential, and longitudinal swelling values of the samples exposed to a temperature of $180^{\circ} \mathrm{C}$ for 10 hours were $11.20,11.11,31.59,35.73$, and 31.77 percent, respectively. Table 2 and Figure 1 also present overall reduction of physical properties of the samples as a result of heat treatment. Low swelling value of the samples is always desirable because it results in better dimensional stability, which can be related to material losses in the cell wall, extractive substances, and degradation of hemicellulose due to the effect of high temperature. It is well known that the weight of wood and its swelling decrease when heat treatment is applied. Heat treatment reduces the hydrophilic behavior of the wood by modifying the chemical structure of some of its components (Raimo et al. 1996, Gailliot 1998, Homan et al. 2000). Such modification prevents the reabsorption of water that would promote wood decay. When wood absorbs moisture from its surroundings, water molecules are attached between and within the wood polymers, lignin, cellulose, and hemicelluloses, so that hydrogen bonds are formed. This phenomenon causes swelling of wood. During heat treatment, the number of hydrophilic $\mathrm{OH}$ groups is decreased and they are replaced by hydrophobic $O$-acetyl groups (Esteves et al. 2007). This creates cross-links between wood fibers and thus it significantly reduces the ability of the water to penetrate into the wood (Homan et al. 2000). Heat-treated wood becomes dimensionally more stable compared to untreated wood. Elimination of hydroxyl groups also reduces the number of potential anchor-points for fungi (Poncsák et al. 2006).
Water absorption of the cell wall because of the decrease in the amount of wood's hydroxyl groups is enhanced. Consequently, having reduced number of hydroxyl groups improves swelling and shrinking of wood (Follrich et al. 2006, Yildiz et al. 2006).

Surface roughness of the samples treated at a temperature of $180^{\circ} \mathrm{C}$ for 10 hours had improved $R_{a}$ values by up to 25.67 percent, which was lower than those of control samples. The heat treatment resulted in a plastification on the solid wood surfaces. High temperatures above $160^{\circ} \mathrm{C}$ cause conversion of lignin into a thermoplastic condition, which increases density and compacting of the surface layer. As a result, in our study surface characteristics of the samples were noticeably enhanced. Solid wood with a rough surface requires more sanding, which not only wastes raw material by decreasing its thickness but also increases overall production cost. Therefore, it appears that heat treatment would be a potential method to improve surface quality of sessile oak.

Table 3 shows the results of mechanical properties of the samples as a result of heat treatment. All mechanical properties of the specimens were adversely affected by the heat treatment. It is known that equilibrium moisture content of heat-treated wood is generally lower than that of regular wood. However, modification in chemical structure of wood is more responsible for reduced strength properties of the samples exposed to heat treatment. The differences between strength properties of the treated and control samples were statistically significant. The samples treated at a temperature of $180^{\circ} \mathrm{C}$ for 10 hours resulted in a maximum reduction in all mechanical properties. The lowest compression strength value was $50.42 \mathrm{~N} / \mathrm{mm}^{2}$, and the total loss compared with the control samples was 21.30 percent. Similarly, the lowest MOR value was $85.52 \mathrm{~N} / \mathrm{mm}^{2}$ for the samples treated at the above conditions (Sanli 2008). 
Table 4.- Reduction in mechanical properties of the samples as function of heat treatment.

\begin{tabular}{|c|c|c|c|c|c|c|c|c|}
\hline \multirow{2}{*}{$\begin{array}{l}\text { Heat } \\
\text { treatment } \\
\text { and time }\end{array}$} & \multirow{2}{*}{$\begin{array}{l}\text { Compression } \\
\text { strength }(\%)\end{array}$} & \multirow{2}{*}{$\begin{array}{l}\text { Bending } \\
\text { strength (\%) }\end{array}$} & \multirow{2}{*}{$\begin{array}{l}\text { Modulus of } \\
\text { elasticity in } \\
\text { bending (\%) }\end{array}$} & \multicolumn{3}{|c|}{ Janka hardness $(\%)$} & \multirow{2}{*}{$\begin{array}{l}\text { Impact bending } \\
\text { strength }(\%)\end{array}$} & \multirow{2}{*}{$\begin{array}{l}\text { Tension strength } \\
\text { perpendicular to } \\
\text { grain }(\%)\end{array}$} \\
\hline & & & & Cross section & Radial & Tangential & & \\
\hline \multicolumn{9}{|l|}{$120^{\circ} \mathrm{C}$} \\
\hline $2 \mathrm{~h}$ & 1.459 & 5.158 & 15.868 & 3.871 & 1.585 & 2.374 & 12.468 & 3.657 \\
\hline $6 \mathrm{~h}$ & 4.368 & 7.253 & 19.584 & 4.504 & 2.378 & 7.035 & 18.621 & 6.678 \\
\hline $10 \mathrm{~h}$ & 4.460 & 8.848 & 19.826 & 4.694 & 5.037 & 10.130 & 18.745 & 7.693 \\
\hline \multicolumn{9}{|l|}{$150^{\circ} \mathrm{C}$} \\
\hline $2 \mathrm{~h}$ & 5.701 & 12.943 & 36.302 & 5.327 & 7.001 & 10.273 & 21.462 & 8.275 \\
\hline $6 \mathrm{~h}$ & 6.573 & 13.117 & 37.233 & 6.488 & 9.166 & 11.705 & 23.756 & 8.773 \\
\hline $10 \mathrm{~h}$ & 7.276 & 19.528 & 37.604 & 7.453 & 9.398 & 11.891 & 25.248 & 14.027 \\
\hline \multicolumn{9}{|l|}{$180^{\circ} \mathrm{C}$} \\
\hline $2 \mathrm{~h}$ & 11.597 & 20.460 & 39.758 & 10.236 & 10.858 & 13.990 & 28.699 & 35.195 \\
\hline $6 \mathrm{~h}$ & 11.730 & 23.279 & 42.415 & 13.333 & 13.749 & 16.774 & 39.276 & 40.234 \\
\hline $10 \mathrm{~h}$ & 21.309 & 35.317 & 45.585 & 17.419 & 17.665 & 19.016 & 45.742 & 45.850 \\
\hline
\end{tabular}

Corresponding average values for MOE, impact strength, tensile strength perpendicular-to-grain, hardness for cross section, and radial and tangential directions were $7,553 \mathrm{~N} /$ $\mathrm{mm}^{2}, 4.428 \mathrm{~J} / \mathrm{cm}^{2}, 3.138 \mathrm{~N} / \mathrm{mm}^{2}, 57.87 \mathrm{~N} / \mathrm{mm}^{2}, 28.38 \mathrm{~N} /$ $\mathrm{mm}^{2}$, and $30.35 \mathrm{~N} / \mathrm{mm}^{2}$, respectively. Figure 2 and Table 4 show reduction in mechanical properties of the samples due to heat treatment. The compression strength and modulus of elasticity of the samples were greatly affected by initial heat treatment, but after that they showed a gradual decrease in their properties with increasing temperatures and treatment times. In general the results of this study in terms of the effect of heat treatment on properties of the samples are comparable to those of a previous study using different species including Pinus pinaster and Eucalyptus globulus (Esteves et al. 2007). Samples of these two species treated by a temperature ranging between $190^{\circ} \mathrm{C}$ and $210^{\circ} \mathrm{C}$ for 2 to 12 hours resulted in increased dimensional stability and surface wettability. Mass losses of the samples increased with increasing treatment time and temperature, reaching 7.3 percent for pine and 14.5 percent for eucalyptus samples. In another study, heat-treated Turkish river red gum (Eucalyptus camaldulensis Dehn.) samples showed reductions in hardness of cross-section, radial, and tangential sections for $23.91,44.20$, and 33.57 percent, respectively, due to similar heat treatment conditions used in this work (Unsal et al. 2003, Unsal and Ayrilmis 2005).

Compression strength parallel-to-grain of Uludag fir (Abies bornmuellerinana Mattf.) samples decreased 29.41 percent when they were exposed to a temperature of $180^{\circ} \mathrm{C}$ for 10 hours (Korkut 2008). In the same study, $60.56 \mathrm{~N} / \mathrm{mm}^{2}$ was the lowest MOR value with a reduction of 29.28 percent as compared with control samples. Effect of heat treatment on mechanical properties of the samples from Camiyanı black pine (Pinus nigra Arn. subsp. pallasiana var. pallasiana) and red-bud maple (Acer trautvetteri Medw.) were also investigated and reduction in different strength properties of the samples were found to be similar to those found in this study (Gunduz et al. 2008, Korkut et al. 2008).

In general the decreases in the strength properties of heat-treated sessile oak samples can be related to thermal degradation and lost of chemical building elements of wood to a certain extent as a result of heat treatment. Strength reduction of the samples is mainly due to the depolymerization reactions of wood polymers (Ayrilmis and Winandy 2009). Degradation of hemicelluloses, which is less resistant to heat than cellulose and lignin, could also be one of the main reasons. Changes in and loss of hemicelluloses play key roles in the strength properties of wood heated at high temperatures (Kamden et al. 1999, Kotilainen 2000).

\section{Conclusions}

This study demonstrated that all mechanical properties of the heat-treated sessile oak samples tested in this work had some reduction as compared with control samples. However, it appears that heat treatment had a limited benefit on dimensional stability and surface roughness of the samples. Treatment temperature was not the only parameter contributing to the reduction of mechanical properties; weight loss directly connected to treatment duration. Due to reduced mechanical properties of sessile oak as a result of heat treatment, it is recommended that such units should not be used for constructional applications.

\section{Acknowledgments}

Some of the data in this study are based on the Master's thesis prepared by Tolunay Sanli, Institute of Science and Technology, Duzce University, Duzce, Turkey. The cooperation of the Robert M. Kerr Food \& Agricultural Products Center (FAPC), Oklahoma State University, is also appreciated.

\section{Literature Cited}

Anonymous. 2001. VIII. Five years development plan. Forestry Private Specialty Commission Report. DPT Publication No. 2531, OIK Publication No. 547. Ankara, Turkey. ISBN 975-19-2555-X.

Anonymous. 2003. ThermoWood Handbook, Finnish Thermowood Association. Wood Focus Oy, Helsinki.

Ayrilmis, N. and J. E. Winandy. 2009. Effects of post thermal-treatment on wettability, surface roughness, and adhesive bonding performance of exterior medium density fiberboard. Mater. Manuf. Process. 24(5): 594-599.

Bekhta, P. and P. Niemz. 2003. Effect of high temperature on the change in colour, dimensional stability and mechanical properties of spruce wood. Holzforschung 57:539-546.

Boonstra, M. J., B. F. Tjeerdsma, and H. C. Groeneveld. 1998. Thermal modification of non-durable wood species. Part 1. The Plato technology: Thermal modification of wood. Document No. IRG/WP 98-40123. International Research Group on Wood Preservation.

Bourgois, J. and R. Guyonnet. 1988. Characterization and analysis of torrified wood. Wood Sci. Technol. 22:143-155. 
Bourgois, P. J., G. Janin, and R. Guyonnet. 1991. The color measurement: a fast method to study and to optimize the chemical transformations undergone in the thermically treated wood. Holzforschung 45:377-382.

Bozkurt, A. Y. and N. Erdin. 1997. Wood material technology handbook. Istanbul University Publication No. 3998, Faculty of Forestry Publication No. 445. Istanbul University, Istanbul, Turkey. ISBN 975-404-449-X.

Bozkurt, A. Y. and N. Erdin. 1998. Important trees in trade. Istanbul University Publication No. 4024, Faculty of Forestry Publication No. 444. Istanbul University, Istanbul, Turkey.

Burmester, A. 1973. Effect of heat-pressure treatments of semi-dry wood on its dimensional stability. Holz Roh-Werkst. 31(6):237-243.

Burmester, A. 1975. The dimensional stabilization of wood. Holz RohWerkst. 33(9):333-335.

Esteves, B., A. V. Marques, I. Domingos, and H. Pereira. 2007. Influence of steam heating on the properties of pine (Pinus pinaster) and eucalypt (Eucalyptus globulus) wood. Wood Sci. Technol. 41(3): 193-207.

Fengel, D. 1966. On the changes of the wood and its components within the temperature range up to $200^{\circ} \mathrm{C}$-Part III: Thermally and mechanically caused structural changes in sprucewood. Holz RohWerkst. 24(11):529-536.

Fengel, D. and G. Wegener. 1989. Wood Chemistry, Ultrastructure, Reactions. Walter de Gruyter and Co., Berlin. 613 pp.

Follrich, J., U. Muller, and W. Gindl. 2006. Effects of thermal modification on the adhesion between spruce wood (Picea abies Karst.) and a thermoplastic polymer. Holz Roh-Werkst. 64:373-376.

Gailliot, F. P. 1998. Extraction and Product Capture in Natural Product Isolation, Cannell. Humana Press, Totowa, New Jersey. pp. 59-68.

Giebeler, E. 1983. Dimensional stabilization of wood by moisture-heatpressure-treatment. Holz Roh-Werkst. 41(3):87-94.

Gunduz, G., S. Korkut, and D. Sevim Korkut. 2008. The effects of heat treatment on physical and technological properties and surface roughness of Camiyanı Black Pine (Pinus nigra Arn. subsp. pallasiana var. pallasiana) wood. Bioresour. Technol. 99(7): 2275-2280.

Hillis, W. E. 1984. High temperature and chemical effects on wood stability. Part 1. General considerations. Wood Sci. Technol. 18: 281-293.

Hiziroglu, S. 1996. Surface roughness analysis of wood composites: A stylus method. Forest Prod. J. 46(7/8):67-72.

Homan, W., B. Tjeerdsma, E. Beckers, and A. Joressen. 2000. Structural and other properties of modified wood. In: World Conference on Timber Engineering, Whistler, British Columbia, Canada. pp. 1-8.

Inoue, M., M. Norimoto, M. Tanahashi, and R. M. Rowell. 1993. Steam or heat fixation of compressed wood. Wood Fiber Sci. 25(3):224-235.

International Organization for Standardization (ISO). 1975. Wooddetermination of density for physical and mechanical tests. ISO 3131. ISO, Geneva.

International Organization for Standardization (ISO). 1997. Geometrical product specifications (GPS) - Surface texture: Profile methodTerms, definitions, and surface texture parameters. ISO 4287. ISO, Geneva.

Kalipsiz, A. 1994. Statistic methods. Istanbul University Publication No. 3835, Faculty of Forestry Publication No. 427. Istanbul University, Istanbul, Turkey. ISBN 975-404-368-X.

Kamden, D. P., A. Pizzi, R. Guyonnet, and A. Jermannaud. 1999 Durability of heat-treated wood. In: Proceedings of the International Research Group on Wood Preservation, Rosenheim, Germany. pp. 115 .

Kocaefe, D., S. Poncsak, and Y. Boluk. 2008a. Effect of thermal treatment on the chemical composition and mechanical properties of birch and aspen. BioResources 3(2):517-537.

Kocaefe, D., J. L. Shi, D. Q. Yang, and M. Bouazara. 2008b. Mechanical properties, dimensional stability, and mold resistance of heat-treated jack pine and aspen. Forest Prod. J. 58(6):88-93.

Kollmann, F. and D. Fengel. 1965. Changes in the chemical composition of wood by thermal treatment. Holz Roh-Werkst. 23(12):461-468.

Kollmann, F. and A. Schneider. 1963. On the sorption-behaviour of heat stabilized wood. Holz Roh- Werkst. 21(3):77-85.

Konukcu, M. 1998. Statistical profile of Turkish forestry. Prime Ministry State Planning Organization, Republic of Turkey, Ankara. 44 pp.
Korkut, S. 2008. The effects of heat treatment on some technological properties in Uluda $\breve{g}$ fir (Abies bornmuellerinana Mattf.) wood. Building Environ. 43(4):422-428.

Korkut, S., M. S. Kok, S. Korkut, and T. Gurleyen. 2008. The effects of heat treatment on technological properties in Red-bud maple (Acer trautvetteri Medw.) wood. Bioresour. Technol. 99(6):1538-1543.

Kotilainen, R. 2000. Chemical changes in wood during heating at 150 $260^{\circ} \mathrm{C}$. Doctoral thesis. University of Jyväskylä, Finland.

Kubojima, Y., T. Okano, and M. Ohta. 2000. Bending strength and toughness of heat-treated wood. J. Wood Sci. 46:8-15.

Militz, H. 2002. Thermal treatment of wood: European processes and their background. IRG/WP 02-40241. In: 33rd Annual Meeting, May 12-17, 2002, Cardiff, Wales 4; International Research Group on Wood Preservation, Cardiff, Wales. pp. 1-17.

Mummery, L. 1993. Surface Texture Analysis-The Handbook. Hommelwerke, Muhlhausen, Germany. 106 pp.

Noack, D. 1969. Über die Heißwasserbehandlung von Rotbuchenholz im Temperaturbereich von 100 bis $180^{\circ} \mathrm{C}$. Holzforsch. Holzverwert. 21 : 118-124.

Poncsák, S., D. Kocaefe, M. Bouazara, and A. Pichette. 2006. Effect of high temperature treatment on the mechanical properties of birch (Betula papyrifera). Wood Sci. Technol. 40(8):647-663.

Raimo, A., E. Kuoppala, and P. Oesch. 1996. Formation of the main degradation compounds groups from wood and its components during pyrolysis. J Anal. Appl. Pyrolysis 36:137-148.

Rusche, H. 1973. Thermal degradation of wood at temperatures up to $200^{\circ} \mathrm{C}$. Part 1: Strength properties of dried wood after heat treatment. Holz Roh-Werkst. 31(7):273-281.

Sandermann, W. and H. Augustin. 1963. Chemical investigations on the thermal decomposition of wood. Part I: Stand of research. Holz RohWerkst. 21(7):256-265.

Sanli, T. 2008. The effects of heat treatment on some technological properties in oak (Quercus petraea (Mattuschka) Liebl. subsp. iberica (Steven ex Bieb) Krassiln) wood. Duzce University, Institute of Science and Technology, Duzce, Turkey. 114 pp.

Seborg, R. M., H. Tarkow, and A. J. Stamm. 1953. Effect of heat upon the dimensional stabilisation of wood. Forest Prod. J. 3(9):59-67.

Stamm, A. J. 1964. Dimensional Stabilization, Wood and Cellulose Science. The Ronald Press Company, New York. pp. 312-342.

Stombo, D. A. 1963. Surface texture measurement. Forest Prod. J. 13(6): 299-304

Syrjänen, T., S. Jämsä, and P. Viitaniemi. 2000. Heat treatment of wood in Finland-State of the art. Technical Research Centre of Finland Building Technology. $12 \mathrm{pp}$.

Syrjanen, T. and K. Oy. 2001. Production and classification of heattreated wood in Finland, Review on heat treatments of wood. In: Proceedings of the Special Seminar, Antibes, France.

Turkish Standards (TS). 1976a. Wood-sampling methods and general requirements for physical and mechanical tests. TS 2470. Turkish Standards Institution, Ankara.

Turkish Standards (TS). 1976b. Wood-Determination of density for physical and mechanical tests. TS 2472. Turkish Standards Institution, Ankara.

Turkish Standards (TS). 1976c. Wood—Determination of ultimate stress in compression parallel to grain. TS 2595. Turkish Standards Institution, Ankara.

Turkish Standards (TS). 1976d. Wood-Determination of ultimate strength in static bending. TS 2474. Turkish Standards Institution, Ankara.

Turkish Standards (TS). 1976e. Wood-Determination of modulus of elasticity in static bending. TS 2478. Turkish Standards Institution, Ankara.

Turkish Standards (TS). 1976f. Wood-Determination of impact bending strength. TS 2477. Turkish Standards Institution, Ankara.

Turkish Standards (TS). 1976g. Wood-Determination of ultimate tensile stress perpendicular to grain. TS 2476. Turkish Standards Institution, Ankara.

Turkish Standards (TS). 1976h. Wood, determination of moisture content for physical and mechanical tests. TS 2471. Turkish Standards Institution, Ankara.

Turkish Standards (TS). 1981. Wood-Sampling and test methodsDetermination of physical properties. TS 53. Turkish Standards Institution, Ankara. 
Turkish Standards (TS). 1982. Wood-Determination of static hardness. TS 2479. Turkish Standards Institution, Ankara.

Turkish Standards (TS). 1983. Wood-Determination of radial and tangential swelling. TS 4084. Turkish Standards Institution, Ankara.

Turkish Standards (TS). 1984. Wood-sampling sample trees and logs for determination of physical and mechanical properties of wood in homogeneous stands. TS 4176. Turkish Standards Institution, Ankara.

Turkish Standards (TS). 1997. Standard atmospheres for conditioning and/or testing; specifications. TS 642. Turkish Standards Institution, Ankara.

Unsal, O. and N. Ayrilmis. 2005. Variations in compression strength and surface roughness of heat-treated Turkish river red gum (Eucalyptus camaldulensisv Dehn.) wood. J. Wood Sci. 51:405-409.
Unsal, O., S. Korkut, and C. Atik. 2003. The effect of heat treatments on some properties and colour in Eucalyptus camaldulensis Dehn. wood. Maderas Cienc. Technol. 5(2):145-152.

Yaltirik, F. and A. Efe. 2000. Dendrology handbook, GymnospermaeAngiospermea. University of Istanbul Publication No. 4265, Faculty of Forestry Publication No. 465. University of Istanbul, Istanbul, Turkey. ISBN 975-404-594-1.

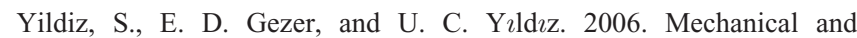
chemicalbehavior of spruce wood modified by heat. Build. Environ. 41(12):1762-1766.

Zaman, A., R. Alen, and R. Kotilainen. 2000. Thermal behavior of Pinus sylvestris and Betula pendula at $200-230^{\circ} \mathrm{C}$. Wood Fiber Sci. 32(2): $138-143$. 